12. E. Darzynkiewicz, Z. Kazimierczuk and D. Shugar. Cancer Biochem. Biophys. 1, 203 (1976).

13. E. De Clereq. E. Darzynkiewicz and D. Shugar, Bioche'm. Pharmac. 24, 523 (1975).

14. M. Fiala, A. W. Chow, K. Miyasaki and L. B. Guze, J. Infect. Dis. 129, 82 (1974).

15. M. I. Marks, Antimicrob. Ag. Chemother. 6, 34 (1974).

16. E. R. Kern, J. C. Overall. Jr. and L. A. Glasgow, Antimicroh. Ad. Chemother. 7. 587 (1975).

17. G. Freeman. A. Kuehn and I. Sultanian, Amr. N.Y. Acad. Sci. 130, $330(1965)$

18. J. B. Campbell, R. F. Maes, T. J. Wiktor and $H$. Koprowski. Virology 34. 701 (1968).
19. J. A. Grant and L. R. Sabina, Antimicrob. Ag. Chemother. 2. 201 (1972).

20. T. Ben-Porat McK. Brown and A. S. Kaplan, Molec Pharmac. 4, 139 (1968).

21. C. Shipman, Jr., S. H. Smith, R. H. Carlson and J. C. Drach, Antimicrob. Ag. Chemother. 9, 120 (1976)

22. J. A. Montgomery and A. G. Laseter, J. med. Chem 17. 360 (1974).

23. J. Giziewicz. E. De Clercq. M. Luczak and D. Shugar. Biochem. Pharmac. 24, 1813 (1975).

\title{
Ascorbic acid and heme synthesis in deficient guinea pig liver
}

\author{
(Received 2 July 1976; accepted 17 September 1976)
}

Ascorbic acid deficiency in guinea pigs results in marked reduction in the activity of the hepatic microsomal drug metabolism system. Examples of the type of reactions affected include $O$-demethylation, $N$-demethylation, hydroxylation, nitroreduction and steroid hydroxylation [1-5]. Furthermore, there is a marked decrease in the quantity of the microsomal electron transport component, cytochrome P-450 [6-8]. Luft et al. [9] found that the quantity of the heme protein, cytochrome P-450, approached normal levels when ascorbic acid-deficient guinea pigs were injected with $\delta$-aminolevulinic acid (ALA), a key substrate in heme synthesis. These authors suggested that the reduced quantity of cytochrome P-450 could be due to an impairment in heme synthesis $[9,10]$. It was important, therefore, to determine the effect of ascorbic acid deficiency on the activities of the key enzymes involved in heme biosynthesis, namely ALA synthetase. ALA dehydratase and ferrochelatase.

Male albino guinea pigs (Hartley strain) weighing $180-200 \mathrm{~g}$ were maintained on an ascorbic acid-deficient diet or on a normal chow diet for 18-21 days as previously described [11]. Animals were sacrificed by decapitation and their livers were perfused in situ with ice-cold physiological saline. Livers were homogenized with a PotterElvehjem glass homogenizer in $0.9_{0}^{\circ} \mathrm{NaCl}$ and $0.01 \mathrm{M}$ Tris $(\mathrm{pH} \mathrm{7.4)}$ for the determination of ALA synthetase activity, in $0.25 \mathrm{M}$ sucrose and $0.01 \mathrm{M}$ Tris ( $\mathrm{pH} 7.4$ ) for ALA dehydratase activity, or in $0.25 \mathrm{M}$ sucrose $0.05 \mathrm{M}$ Tris ( $\mathrm{pH} 8.0$ ) and $0.001 \mathrm{M}$ EDTA for ferrochelatase activity.

ALA synthetase activity was determined using a modification of the radiochemical assay of Ebert et al. $\lceil 12\rceil$ with $\left[2,3-{ }^{14} \mathrm{C}\right]$ succinate as the substrate. One $\mathrm{ml}$ of whole liver homogenate $\left(2.5\right.$ to $\left.5 \%, \mathrm{w}_{/} \mathrm{v}\right)$ was added to $1 \mathrm{ml}$ of a solution containing $200 \mathrm{mM}$ glycine, $150 \mathrm{mM}$ Tris (pH 7.4), $20 \mathrm{mM}$ EDTA. $0.4 \mathrm{mM}$ pyridoxal phosphate and $1 \mu \mathrm{Ci}$ $\left[{ }^{14} \mathrm{C}\right]$ succinate $(22.5 \mathrm{mCi} / \mathrm{m}$-mole $)$. Incubations were carried out at 37 for $10 \mathrm{~min}$ and the reaction was terminated with $0.25 \mathrm{ml}$ of $50^{\circ}$ " trichloroacetic acid. The trichloroacetic acid supernatants were prepared for chromatography according to Ebert et al. [12] and subsequently added to columns of Dowex $50-\mathrm{Na}^{+}$resin $(100-200$ mesh). The columns were washed with $20 \mathrm{ml}$ methanol- $-0.05 \mathrm{M}$ acetate buffer $(\mathrm{pH} 4.0)(2: 1, \mathrm{v} / \mathrm{v})$, washed with $10 \mathrm{ml}$ of $0.1 \mathrm{M}$ $\mathrm{HCl}$. and the $\left[{ }^{1+} \mathrm{C}\right] \mathrm{ALA}$ eluted with $1 \mathrm{M} \mathrm{NH} \mathrm{N}_{4} \mathrm{OH}$. The initial ? mil of $1 \mathrm{M} \mathrm{NH}_{4} \mathrm{OH}$ eluate was discarded, since it did not contain appreciable radioactivity. $\left[{ }^{14} \mathrm{C}\right] \mathrm{ALA}$ was eluted in the subsequent $3 \mathrm{ml}$ of $1 \mathrm{M} \mathrm{NH}_{4} \mathrm{OH}$. Aliquots $(0.5 \mathrm{ml})$ were added to $10 \mathrm{ml}$ naphthalene dioxane scintillation fluid and counted. The recovery of $\left[{ }^{14} \mathrm{C}\right] \mathrm{ALA}$ from Dowex columns was monilored using $0.01 \mu \mathrm{Ci}\left[{ }^{14} \mathrm{C}\right] \mathrm{ALA}$ $(25.4 \mathrm{mCi} / \mathrm{m}$-mole) and was $81 \pm 3$ per cent. Enzyme activity was corrected for this recovery. ALA synthetase activity was also determined in sonicated liver mitochondria [13] to eliminate possible effects on activity arising from differences in mitochondrial integrity or amounts of endogenous cofactors present. Washed mitochondria were diluted to $1 \mathrm{mg}$ protein $/ \mathrm{ml}$ and sonicated using two $5-\mathrm{sec}$ bursts at $4-8 \mathrm{~A}$ with a model S 125 Bronson sonifier. The incubation mixture $(2 \mathrm{ml})$ contained $200 \mu \mathrm{g}$ of mitochondrial protein, $75 \mathrm{mM}$ Tris (pH 7.4), $10 \mathrm{mM}$ EDTA, $125 \mathrm{mM}$ sucrose, $10 \mathrm{mM} \mathrm{MgCl} 2,100 \mathrm{mM}$ glycine, $0.2 \mathrm{mM}$ pyridoxal phosphate, $0.1 \mathrm{mM}$ GTP, $0.1 \mathrm{mM}$ CoA, 0.5 unit succinyl $\mathrm{COA}$ synthetase (Succinic thiokinase from the Sigma Chemical Co.) and $1 \mu \mathrm{Ci}\left[{ }^{14} \mathrm{C}\right]$ succinate $(22.5 \mathrm{mCi} / \mathrm{m}$ mole). Incubations were carried out at 37 for periods up to $15 \mathrm{~min}$ and the $\left[{ }^{14} \mathrm{C}\right] \mathrm{ALA}$ formed was isolated and counted as described above. The modifications described were necessary to obtain guinea pig ALA synthetase activity which was proportional to enzyme concentration (up to $12 \mathrm{mg}$ of whole homogenate protein or $200 \mu \mathrm{g}$ of sonicated mitochondrial protein) and linear with time for at least $15 \mathrm{~min}$.

ALA dehydratase activity was determined in $15,000 \mathrm{~g}$ supernatant fractions from guinea pig livers according to the method of Gibson et al. [14] except that the reaction was terminated with $1.0 \mathrm{ml}$ of $10^{\circ}$ trichloroacetic acid and $0.1 \mathrm{M} \mathrm{HgCl}_{2}$. The amount of product, porphobilinogen, was measured directly in the deproteinized supernatants with Erlich's reagent using a molar extinction coefficient of 61,000 [15]; its recovery from liver supernatant fractions was greater than 94 per cent. In other experiments, porphobilinogen was isolated by column chromatography on Dowex 1-acetate [16]

Ferrochelatase activity was determined in liver mitochondria by the method of Wagner and Tephly [17], which measures the incorporation of ${ }^{59} \mathrm{Fe}$ into heme under anaerobic conditions. Ferrochelatase activity was proportional to enzyme concentration ( 1.5 to 4.0 protein $/ \mathrm{ml})$ and linear with time for at least $40 \mathrm{~min}$. The labeled heme was extracted into cyclohexanone as described by Jones [18] 
Table 1 . Liver $\delta$-aminolevulinic acid synthetase activity in normal and ascorbic acid-deficient guinea pigs*

\begin{tabular}{|c|c|c|c|c|}
\hline \multirow[b]{2}{*}{ Treatment } & \multicolumn{2}{|c|}{ ALA synthetase } & \multirow{2}{*}{$\begin{array}{c}\text { Cytochrome } \\
\mathrm{P}-450 \div \\
\text { (nmoles } 100 \mathrm{mg} \text { ) }\end{array}$} & \multirow[b]{2}{*}{$\begin{array}{l}\text { Ascorbic acids } \\
\text { (nmoles } 100 \mathrm{mg} \text { ) }\end{array}$} \\
\hline & $\begin{array}{c}\text { Homogenatef } \\
\text { (nmoles } \mathrm{hr} / 100 \mathrm{mg} \text { ) }\end{array}$ & $\begin{array}{c}\text { Mitochondriat } \\
\text { (nmoles hr } 100 \mathrm{mg} \text { ) }\end{array}$ & & \\
\hline Normal & $16.5 \pm 2.3(12)$ & $680 \pm 50(5)$ & $19.2 \pm 1.1(12)$ & $1740 \pm 190(12)$ \\
\hline Fed & $15.2 \pm 3.3(8)$ & & & \\
\hline Starved & $18.9 \pm 2.3(4)$ & & & \\
\hline Ascorbate-Deficient & $18.1 \pm 1.9(11)$ & $720 \pm 90(5)$ & $9.5 \pm 0.7(11)$ & $99 \pm 7(11)$ \\
\hline
\end{tabular}

* Normal guinea pigs reccived $1 \mathrm{mg}$ ascorbic acid $\mathrm{ml}$ in their drinking water daily Ascorbic acid-deficient animals were on the diet 18 days. Values are means \pm S.E.; number in parentheses equals number of animals.

+ Activity equals nmoles ALA formed hr $100 \mathrm{mg}$ of whole cell homogenate or sonicated mitochondrial protein at 37.

$\$$ Cytochrome P-450 was determined in the liver $15,000 \mathrm{~g}$ supernatant fraction: $\mathrm{CO}$ was present in control and experimental cuvettes and dithionite was added only to the experimental cuvette. Quantity of P-450 equals nmoles:100 mg of protein: $P<0.01$.

$\$$ Ascorbic acid was determined in the liver 15.000 \& supernatant fraction [21]. Quantity equals nmoles 100 mg of protein.

A 2-ml aliquot of the cyclohexanone fiaction was washed with $8 \mathrm{ml}$ of $0.5 \mathrm{~N} \mathrm{HCl}$ saturated with cyclohexanone before determining the radioactivity in a $0.1-\mathrm{ml}$ sample by liguid ceintillation spectrometry

Liver eytochrome P-450 and ascorbic acid were measured in $15,000 \mathrm{~g}$ supernatant fractions as previously described [11]. Protein was determined by the method of Lowry et al. [19].

Table 1 gives the activity of ALA synthetase, the quantity of cytochrome P-450 and the ascorbic acid in livers from ascorbic acid-deficient and normal guinea pigs. Ascorbic acid-deficient guinea pigs contained half the amount of cytochrome P-450 compared with normal animals (9.5 vs 19.2 nmoles $100 \mathrm{mg}$ of supernatant protein). In spite of the decrease in cytochrome P-450. ALA synthe- tase activity was not significantly different between the two groups in either whole cell homogenate (18.1 is 16.5 nmoles $/ \mathrm{hr} / 100 \mathrm{mg}$ of protein) or sonicated mitochondria (720) vs 680). The possibility existed that the deficient animals had a lower caloric intake which might affect synthelase activity [20]; therefore, a group of normal animals were starved for $24 \mathrm{hr}$ prior to sacrifice. ALA synthetase activity was somewhat higher in starved compared with fed animals ( 18.9 vs 15.2 nmoles/hr $100 \mathrm{mg}$ ), but the difference was not statistically significant.

The results obtained for $A \mathrm{~L} A$ dehydratase activity in livers from ascorbic acid-deficient and normal guinea pigs are given in Table 2. Whereas cytochrome P-450 was $5.6 \mathrm{nmoles} / 100 \mathrm{mg}$ of protein in deficient animals and 15.9 in normal animals, ALA dehydratase activity was not sub-

Table 2. Liver $\delta$-animolevulinic acid dehydratase activity in normal and ascorbic aciddeficient guinea pigs*

\begin{tabular}{lccc}
\hline Treatment & $\begin{array}{c}\text { ALA dehydratase } \\
\text { (nmoles } / \text { hr/100 mg) }\end{array}$ & $\begin{array}{c}\text { Cytochrome P-450 } \\
\text { (nmoles/100 mg) }\end{array}$ & $\begin{array}{c}\text { Ascorbic acids } \\
\text { (nmoles } / 100 \mathrm{mg})\end{array}$ \\
\hline $\begin{array}{l}\text { Normal (5) } \\
\begin{array}{c}\text { Ascorbic acid- } \\
\text { deficient (5) }\end{array}\end{array}$ & $1056 \pm 53$ & $15.9 \pm 1.1$ & $1560 \pm 170$ \\
\hline
\end{tabular}

* Normal guinca pigs received $1 \mathrm{mg}$ ascorbic acid $\mathrm{ml}$ in their drinking water. daily. Ascorbic acid-deficient animals were on the diet 21 days. Values are means \pm S.E. number in parentheses equals number of animals.

+ Activity equals nmoles porphobilinogen formed hr $100 \mathrm{mg}$ of $15,000 \mathrm{~g}$ supernatant fraction protein at 37 .

$\$$ See footnote to Table $1: \mathrm{P}<0.01$.

See footnote to Table 1.

Table 3. Liver ferrochelatase activity in normal and ascorbic acid-deficient guinea pigs*

\begin{tabular}{lccc}
\hline Treatment & $\begin{array}{c}\text { Ferrochelatase } \\
(\text { nmoles } / \text { hr } / 100 \mathrm{mg})\end{array}$ & $\begin{array}{c}\text { Cytochrome P-450 } \\
(\text { nmoles/100 mg) }\end{array}$ & $\begin{array}{c}\text { Ascorbic acids } \\
\text { (nmoles/100 mg) }\end{array}$ \\
\hline $\begin{array}{l}\text { Normal } \\
\begin{array}{l}\text { Ascorbic acid- } \\
\text { deficient }\end{array}\end{array}$ & $536 \pm 33(9)$ & $21.8 \pm 0.7(6)$ & $1880 \pm 80(6)$ \\
\hline
\end{tabular}

* Normal guinea pigs received $1 \mathrm{mg}$ ascorbic acid/ml in their drinking water, daily. Ascorbic acid-deficient animals were on the diet for 21 days. Values are means \pm S.E.; number in parentheses equals number of animals.

$\dagger$ Activity equals ${ }^{59} \mathrm{Fe}$ incorporated $/ \mathrm{hr} / 100 \mathrm{mg}$ of mitochondrial protein

+ See footnote to Table 1: $\mathrm{P}<0.01$

S See foolnote lo Table 1 . 
stantially different $(922$ vs $1056 \mathrm{nmoles} / 100 \mathrm{mg}$ of protein). In addition, there were no significant differences in ALA dehydratase activity between normal and deficient animals when the product, phorphobilinogen, was isolated on Dowex 1-acetate.

Since iron must be maintained in its ferrous state for incorporation by ferrochelatase into protoporphyrin IX [22], the effect of ascorbic acid deficiency on this enzyme was of interest. As can be seen in Table 3, although the quantity of cytochrome $\mathrm{P}-450$ in ascorbic acid deficient animals was markedly decreased $(8.3$ vs 21.8 nmoles/ $100 \mathrm{mg}$ of protein), there were no significant differences in ferrochelatase activity ( 589 vs $536 \mathrm{nmoles} / \mathrm{hr} / 100 \mathrm{mg}$ of protein).

Contrary to the proposal that the initial and rate-limiting steps in heme synthesis might be impaired in ascorbic acid deficiency $[9,10]$, our results indicate no significant differences in ALA synthetase activity in either whole cell homogenates or sonicated mitochondria. In addition, there were no substantial differences in ALA dehydratase or in ferrochelatase activities. Thus, ascorbic acid deficiency does not affect the activities of the key enzymes involved in heme synthesis. However, the possibility that it might be involved in the synthesis of the apoprotein of cytochrome $\mathrm{P}-450$ or in the degradation of the heme protein should be considered.

Acknowledgement-This study was supported, in part, by Grant 23007 from Hoffmann-La Roche, Inc., Nutley N.J.

Department of Pharmacology,

LORA E. RIKANS

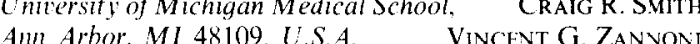

\section{REFERENCES}

1. A. H. Conney, G. A. Bray, C. Evans and J. J. Burns, Ann. N.Y. Acad. Sci. 92, 115 (1961).

2. A. H. Conney and J. J. Burns, Adv. Pharmac. 1, 31 (1962).
3. V. G. Zannoni and M. M. Lynch. Drug Metah. Rev. 2, 57 (1973).

4. V. G. Zannoni, M. M. Lynch and P. H. Sato, in Perinatal Pharmacology: Problems and Priorities (Eds. J Dancis and J. C. Hwang), p. 131. Raven Press, New York (1974).

5. E. Ginter, Science, N.Y. 179, 702 (1973).

6. V. G. Zannoni and P. H. Sato, Amm. N.Y. Acad. Sci. 258, 119 (1975).

7. E. Degkwitz and K. S. Kim, Hoppe-Sevler's Z. physiol. Chem. 354, 555 (1973).

8. V. G. Zannoni, E. J. Flynn and M. Lynch. Biochem Pharmar. 21, 1377 (197))

9. D. Luft, E. Degkwitz. L. Höchli-Kaufmann and $\mathrm{H}$. Staudinger, Hoppe-Seyler's Z. physiol. Chem. 353, 1420 (1972).

10. E. Degkwitz, S. Walsch, M. Dubberstein and J. Winter, Ann. N.Y. Acad. Sci. 258, 201 (1975).

11. P. H. Sato and V. G. Zannoni. J. Pharmac. exp. Ther. 198. 295 (1976).

12. P. S. Ebert, D. P. Tschudy, J. N. Choudhry and M. A. Chirigos, Biochim. biophys. Acta 208, 236 (1970).

13. G. M. Patton and D. S. Beattie, J. hiol. Chem. 248 , 4467 (1973)

14. K. D. Gibson, A. Neuberger and J. J. Scott, Biochem. J. 61, 618 (1955).

15. D. Mauzerall and S. Granick, J. biol. Chem. 219, 435 (1956).

16. H. S. Marver, D. P. Tschudy, M. G. Perlroth, A. Collins and G. Hunter. Jr., Analyt. Biochem. 14, 53 (1966).

17. G. S. Wagner and T. R. Tephly, Adr. exp. Med. Biol. 58, 343 (1975).

18. O. T. G. Jones. Biochem. J. 107, 113 (1968).

19. O. H. Lowry, N. J. Rosebrough, A. L. Farr and R. J. Randall, J. biol. Chem. 193, 265 (1951).

20. H. J. Kim and G. Kikuchi. Archs Biochem. Biophis. 164, $293(1974)$

21. V. Zannoni, M. Lynch, S. Goldstein and P. Sato, Biochem. Med. 11, 41 (1974).

22. R. J. Porra and O. T. G. Jones, Biochem. J. 87, 181 (1963).

\title{
Acute and chronic effects of (-)-amphetamine on seizure threshold and brain catecholamines in mice
}

\author{
(Receined 16 July 1976; accepted 27 September 1976)
}

Amphetamine has been employed for over 35 years for the treatment of epilepsy $[1,2]$. While the acute and chronic effects of $(+)$-amphetamine on the seizure susceptibility of rodents have been the subject of numerous publications [3-9], few studies have examined the effects of its $(-)$-isomer on changes in seizure threshold $[4,8,9]$. We have recently reported that acute administration of (-)-amphetamine at doses of 1.25 to $10 \mathrm{mg} / \mathrm{kg}$ increases seizure threshold in mice by 12-49 per cent, while doses of $1545 \mathrm{mg} / \mathrm{kg}$ were without effect [?]

The present study was designed to determine whether (-)-amphetamine-induced changes in pentylenetetrazol (PTZ) seizure threshold (a model system for central excitation) could be correlated with drug-induced alterations in endogenous concentrations of brain norepinephrine and dopamine and their rates of biosynthesis. Two doses of $(-)$-amphetamine were compared, 4 and $15 \mathrm{mg} / \mathrm{kg}$. the former highly effective in elevating seizure threshold after acute administration and the latter previously observed to be ineffective in this test system [9]. It was also of interest to ascertain whether chronic (-)-amphetamine administration for 7 days could produce alterations in these neuropharmacological and neurochemical parameters, when compared with acute drug treatment.

Materials and methods

Animals. Malc albino CD-1 mice (Charles Rivers) weighing $20-30 \mathrm{~g}$ were used in this study. The animals were housed in groups of $5-10$ mice in cages of $16.5 \times 28 \mathrm{~cm}$ and permitted free access to food (Purina rat chow) and water. The animal quarters were illuminated for $12 \mathrm{hr}$, alternating with $12 \mathrm{hr}$ of darkness.

Drug-dosing schedule. Saline and (-)-amphetamine sulfate were administered i.p. in a constant volume of 